\title{
SEMI-INTENSIVE FATTENING SUITABILITY AND SLAUGHTER VALUE OF YOUNG BULLS OF THREE POLISH NATIVE BREEDS IN COMPARISON WITH POLISH HOLSTEIN-FRIESIAN AND SIMMENTAL*
}

\author{
Zygmunt Litwińczuk ${ }^{1 \bullet}$, Paweł Żółkiewski¹, Mariusz Florek², Witold Chabuz'1, Piotr Domaradzki² \\ ${ }^{1}$ Department of Breeding and Conservation of Genetic Resources of Cattle, \\ ${ }^{2}$ Department of Commodity Science and Animal Raw Materials Processing, \\ University of Life Sciences in Lublin, Akademicka 13, 20-950, Lublin, Poland \\ •Corresponding author: zygmunt.litwinczuk@up.lublin.pl
}

\begin{abstract}
An evaluation was conducted of the suitability for fattening in a semi-intensive system (mainly with fodders from permanent grassland) and the slaughter value of 15 young bulls of the Polish Red (PR) breed and 10 each of the White-Backed (WB) and Polish Black-and-White (BW) breeds. The reference group consisted of young bulls of the Black-and-White variety of the Polish Holstein-Friesian (HF) breed and the Simmental (SIM) breed, fattened on the same farms. Control fattening was carried out until the age of 18 months. Mean daily weight gain in the bulls of the native breeds during the control fattening period (which lasted 314-358 days) was $0.9 \mathrm{~kg}$, similarly to $\mathrm{HF}$, but significantly lower $(\mathrm{P} \leq \mathbf{0 . 0 5})$ than in the Simmentals $(986 \mathrm{~g})$. During the entire fattening period, i.e. from birth to the age of 18 months, daily weight gain was $832 \mathrm{~g}$ in PR and 889-919 $\mathrm{g}$ in WB and BW. Dressing percentage was lowest in PR bulls $(51.69 \%)$, and higher in WB (53.1\%) and $\mathrm{BW}(53.49 \%)$, with values similar to the reference group, i.e. young bulls of the Simmental $(52.97 \%)$ and HF (53.29\%) breeds. The difference between PR and BW (1.8\%) and HF (1.6\%) was statistically significant $(\mathbf{P} \leq \mathbf{0 . 0 5})$. In the EUROP classification system, the carcasses of the young bulls of the native breeds were most often placed in classes $\mathrm{R}^{-}$and $\mathrm{O}^{+}$(conformation) and $2^{+}$and $3^{-}$ (fat cover), as in the case of young HF bulls. Carcasses of young Simmental bulls were assigned to much higher classes. The young bulls of the three Polish native breeds evaluated are good material for fattening in a semi-intensive system (mainly with fodder from permanent grasslands), while the young PR bulls were the least suitable.
\end{abstract}

Key words: cattle, native breeds, semi-intensive fattening, daily weight gain, slaughter value

* Research was realized within the project "BIOFOOD - innovative, functional products of animal origin" no. POIG.01.01.02-014-090/09 co-financed by the European Union from the European Regional Development Fund within the Innovative Economy Operational Programme 2007-2013. 
For centuries local breeds of cattle were used in Poland for production of both milk and meat. In the Middle Ages, more productive breeds with markedly improved milk or meat performance began to be brought in from abroad. The 20th century brought the decline of the dominance of native cattle breeds in Europe (Hiemstra et al., 2010; Litwińczuk, 2011; Spaltabaka, 2009).

In order to preserve the valuable properties of native breeds, from the mid-20th century programmes for protecting genetic resources began to be introduced. In Poland, the first breed to be included in the programme was Polish Red (in 1979), followed by White-Backed (in 2003), and Polish Black-and-White and Polish Redand-White (in 2006 and 2007) (Litwińczuk, 2011). Breeders keeping native breeds received financial support to compensate them for low productivity. These payments are an important stimulus for the development of breeding of these breeds (Adamczyk et al., 2008; Chabuz et al., 2013).

All four native Polish breeds are used for both milk and meat production. Most often, however, they are used for milk production, and bulls are sold as calves for slaughter or for further fattening. In the last 2-3 years several studies have been published analysing the nutritional value and technological suitability of milk obtained from native breeds of cows (Barłowska, 2007; Litwińczuk et al., 2012 a). However, there have been no in-depth studies on the meat performance of native breeds, i.e. Polish Red, White-Backed, Polish Black-and-White and Polish Red-and-White. In the 1960s and 1970s several studies were conducted (Cieślar and Wawrzyńczak, 1978; Zalewski, 1965) to evaluate the meat performance of Polish Red cattle. In intensive fattening systems young bulls were found to achieve weight gain of 900-1000 g; however, the lean meat percentage in the carcass was lower than in other breeds evaluated. In the 1970s many studies were published on the fattening capacity and slaughter value of Polish Black-and-White cattle, then called Polish Black-and-White Lowland (Litwińczuk, 1979; Reklewski et al., 1985; Romer et al., 1978; Ziemiński, 1993). However, as 30-40 years have now elapsed (at least a dozen generations), it is now necessary to evaluate the meat performance of the current population of these two native cattle breeds included in the genetic resources protection programme. After several hundred years during which White-Backed cattle were raised on Polish land, in 2012 the first study was published reporting preliminary results on the slaughter value of this breed (Litwińczuk et al., 2012 b).

The aim of the study was to evaluate the suitability for fattening and slaughter value of young bulls of three native Polish breeds included in the genetic resources protection programme: Polish Red, White-Backed, and Polish Black-and-White. The reference group consisted of young bulls of the Black-and-White variety of Polish Holstein-Friesian breed and the Simmental breed, fattened on the same farms.

\section{Material and methods}

The subjects of the study were 60 young bulls fattened on 2 farms in eastern Poland raising native cattle breeds. On farm I, located in Polesie (a region of central-eastern Poland), young bulls of the White-Backed and Polish Black-and-White 
breeds were fattened (10 of each breed). On farm II, in a sub-mountainous region (south-eastern Poland) 15 young Polish Red bulls, 15 Simmentals, and 10 Polish Holstein-Friesians of the Black-and-White variety were fattened. On both farms the animals were housed in a tie-stall system. After a period of feeding with milk and milk substitutes, the calves were fed on grass forage and hay supplemented by concentrate feed. During the control fattening period, feeding on farm I was based on haylage $(47 \% \mathrm{DM})$ and maize silage $(40 \% \mathrm{DM})$ in the winter, and grass forage $(46 \%)$, haylage $(22 \%)$ and maize silage $(19 \%)$ in the summer. On farm II the young bulls were fed maize silage (43\% DM) and hay (46\%) in the winter and mainly grass forage (52\%) supplemented with maize silage (19\%) and hay $(16 \%)$ in the summer. On both farms the feed rations were supplemented with small amounts of grain meal (about 11-12\%). The young bulls included in the experiment were reared on the farms themselves or purchased at the age of 1-3 months, with the first summer season considered to be the rearing period. The control fattening lasted about 12 months, i.e. between the ages of 6 and 18 months, and included a winter feeding period and the second summer period. After fattening was completed the young bulls underwent control slaughter in accordance with meat industry regulations and under veterinary inspection. Dressing percentage was determined and the carcasses were evaluated according to the EUROP system. The conformation classes were converted to points (according to Alberti et al., 2008), where class P-corresponds to 1 point and class S+ to 18 points, and fat cover was expressed on a 15 -point scale ( 1 - very poor fat cover, 15 - very high fat cover).

For the statistical analysis one-way ANOVA was performed using STATISTICA ver. 9 software. Significance of differences between means was determined by Duncan's test.

\section{Results}

The data in Table 1 show that the age of the experimental animals, i.e. young bulls of 3 native breeds, on the first day of control fattening, i.e. winter feeding, ranged from 191.4 days for the White-Backed breed to 207.2 for the Polish Red breed, and body weight ranged from $196.3 \mathrm{~kg}$ in the White-Back breed to $210.0 \mathrm{~kg}$ in Polish Black-and-White. In the reference group, which was composed of young bulls of the Polish Holstein-Friesian and Simmental breeds (fattened on the same farms as the native breeds), body weight was similar, i.e. $197.7 \mathrm{~kg}$ for HF and $197 \mathrm{~kg}$ for SIM, and age was 205.8 and 223.2 days, respectively.

During the winter feeding period, the daily weight gain in the young bulls of the native breeds was $734 \mathrm{~g}$ in the Polish Red, $848 \mathrm{~g}$ in the White-Backed and $922 \mathrm{~g}$ in the Polish Black-and-White $(\mathrm{P} \leq 0.01)$. During this period the daily weight gain for the HF young bulls averaged $899 \mathrm{~g}$, and for the Simmentals $954 \mathrm{~g}(\mathrm{P} \leq 0.01)$. Markedly higher body weight gain was obtained in each breed during the summer feeding season, when the animals were fed grass forage and maize silage. They were $916 \mathrm{~g}$ for Polish Black-and-White, $943 \mathrm{~g}$ for White-Backed and $961 \mathrm{~g}$ for Polish Red. The body weight calculated for the experimental animals at the age of 18 months ranged from $487.3 \mathrm{~kg}$ in Polish Red to $533.4 \mathrm{~kg}$ in Polish Black-and-White $(\mathrm{P} \leq 0.05)$. 


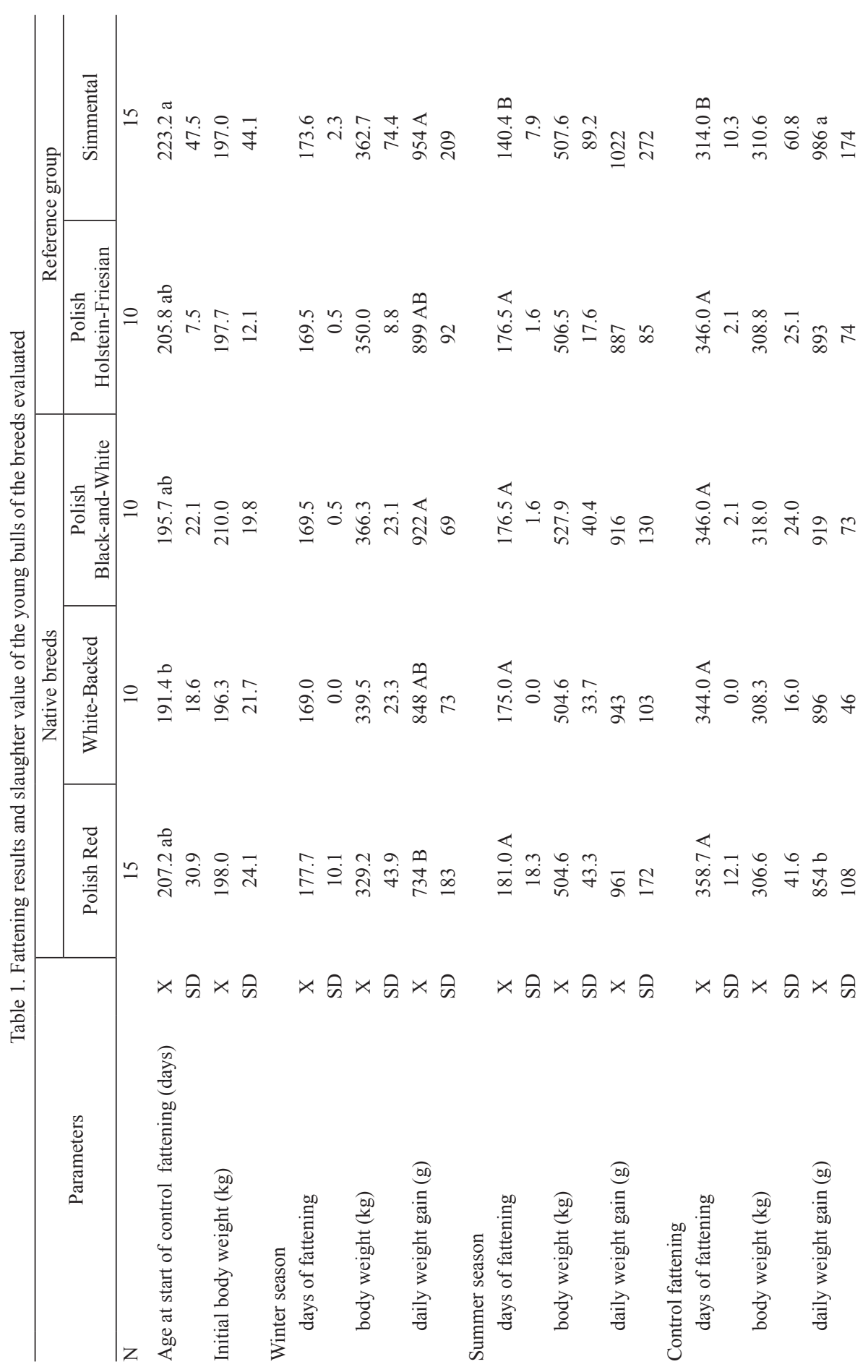




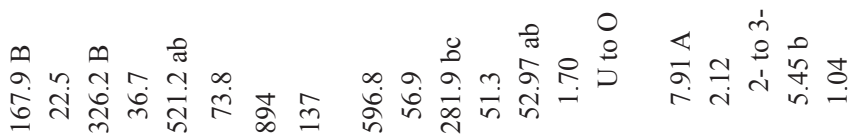

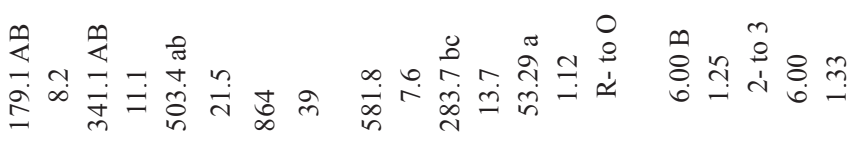

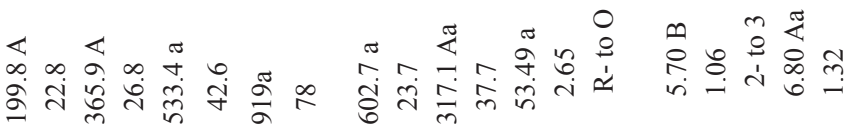

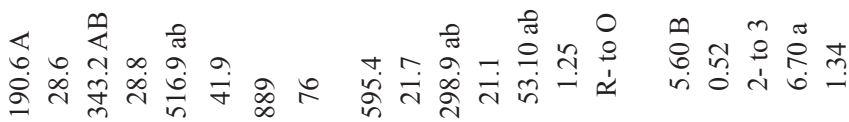

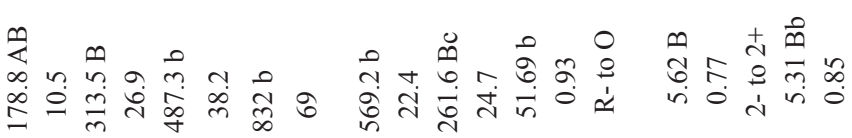

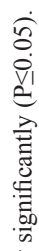

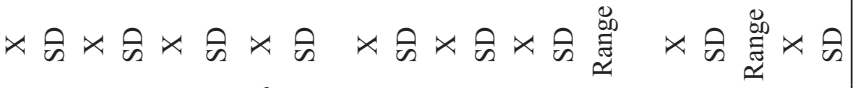

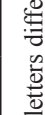

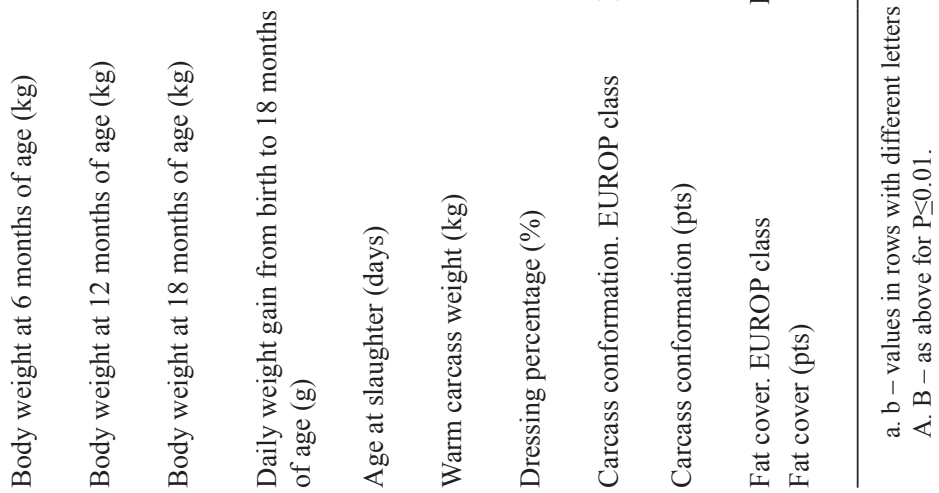


During the entire period of control fattening with on-farm fodder, which lasted 314-358 days (depending on the breed), the average daily weight gain in the young bulls of native breeds ranged from $854 \mathrm{~g}$ in the Polish Red to 896-919 $\mathrm{g}$ in the WhiteBacked and Polish Black-and-White. Thus the weight gain was similar to that of the young HF bulls (893 g) and lower than in the Simmentals (986 g). The difference (132 g) between the Simmental and Polish Red breeds was statistically significant $(\mathrm{P} \leq 0.05)$.

The results presented in Table 1 show that the lowest daily weight gain for the entire fattening period, i.e. from birth to the age of 18 months, was observed in the young bulls of the Polish Red breed (832 g), and the highest in the Polish Black-andWhite breed $(919 \mathrm{~g})$. The difference $(87 \mathrm{~g})$ was statistically significant $(\mathrm{P} \leq 0.05)$.

The warm dressing percentage in the young bulls of native breeds (Table 1) ranged from 51.69\% in the Polish Red breed to 53.1\% and 53.49\% in the White-Backed and Polish Black-and-White breeds, and was similar to that obtained for the reference group, i.e. young bulls of the Simmental (52.97\%) and HF (53.29\%) breeds. In the $\mathrm{PR}$ breed it was significantly lower than in BW and HF $(\mathrm{P} \leq 0.05)$. Evaluation of carcasses in the EUROP classification system placed the young bulls of native breeds in classes from $\mathrm{R}$ - to $\mathrm{O}$ in terms of conformation (irrespective of breed), and in terms of fat cover, in classes from 2- to 2+ (in PR) and 2- to 3 in WB and BW. The young $\mathrm{HF}$ bulls were similarly classified in terms of conformation and fat cover. In contrast, carcasses of the Simmental breed were rated considerably higher in terms of conformation, from class $\mathrm{U}$ to class $\mathrm{O}$, and in terms of fat cover, from 2- to 3-.

\section{Discussion}

The relatively high daily weight gain in the young bulls of the PR breed during the summer feeding season (961 g) was probably linked to compensation for the lowest weight gain during the winter period $(734 \mathrm{~g})$. This is confirmed in the available literature (Choroszy and Choroszy, 2005; Szarek et al., 2004). The weight gain in the young Simmental bulls raised on the same farm during this time, i.e. the summer feeding season, averaged 1,022 g, and in the Polish Holstein-Friesians, $887 \mathrm{~g}$.

The results of the fattening of young bulls of native breeds are similar to those reported in an earlier study by Litwińczuk et al. (2012 b), which showed that young White-Backed bulls gained on average $881 \mathrm{~g} /$ day, Polish Black-and-White $855 \mathrm{~g}$ and HF 869 g. Holló et al. (2012) drew attention to the considerable fattening capacity of the Simmental breed, even in a semi-intensive system. A diet based on maize silage supplemented with concentrate containing $11 \%$ protein resulted in a slaughter weight of $624 \mathrm{~kg}$ at the age of 21 months, which means average daily weight gain of $1,040 \mathrm{~g}$.

The daily weight gain obtained in the young bulls of the three native breeds for the entire fattening period, i.e. from birth to 18 months, ranging from $832 \mathrm{~g}$ in PR to $919 \mathrm{~g}$ in BW, indicates that they are well suited to fattening in a semi-intensive system mainly based on fodder from permanent grassland. In contrast, a relatively 
low daily weight gain during this period was obtained in the young bulls of the Simmental breed $(894 \mathrm{~g})$. This is linked to the relatively low weight gain during the rearing period $(710 \mathrm{~g})$ and to a fattening period that was too short, i.e. only to the age of 18 months. Simmentals are a late-maturing breed, which was emphasized by Trautman et al. (1990), who also pointed out the difficulties in rearing Simmental calves in the first few weeks after birth.

The lowest dressing percentage (51.7\%) was obtained in the young bulls of the PR breed, and significantly the highest in BW (53.5\%). The dressing percentage of the young Simmental bulls was also 53\%, and was probably due to the feeding system used (mainly roughage feed) and the young age of the animals, which translated into low fat cover in the carcasses (classes from 2- to 3-). Oprządek et al. (2007) report that young Polish Red bulls fattened in an intensive system to the age of 12 months attained dressing percentage of 54.45\%, while that of Polish HolsteinFriesians was $50.94 \%$.

The carcass conformation of the young bulls of the three native breeds fattened in the same system was very similar, and comparable to the carcasses of the HF young bulls. On the 15-point EUROP scale it averaged from 5.60 to 6.0. The best conformation was noted in the carcasses of the young Simmental bulls (7.90), and the difference was statistically significant $(\mathrm{P} \leq 0.05)$. Holló et al. (2012) report that young bulls of the native breed Hungarian Grey attained 6.20 points for conformation and 6.8 for fat cover, while in Hungarian Simmentals conformation was only 0.17 less on an 18point scale than in young Charolais bulls (9.50). Alberti et al. (2008) reported scores of only 5.1 for conformation and 9.1 for fat cover in Danish Red fattening bulls. Dannenberger et al. (2006) showed that in pasture-fed Simmental fattening bulls the round was heavier by $7 \%$, the short loin by $13 \%$, and the ribs prepared and chucksquare cut by $2.3 \%$ in comparison with intensively-fed Holstein-Friesians.

To sum up, the young bulls of the three evaluated native breeds, i.e. Polish Red, White-Backed, and Polish Black-and-White, are good material for fattening in a semi-intensive system based on fodder from permanent grassland. They achieve daily weight gain from 0.8 to $0.9 \mathrm{~kg}$ and their carcasses have relatively good conformation and low fat cover. The poorest results, however, were obtained for the young bulls of the Polish Red breed. The values for most of the indicators assessed for the 3 breeds were similar to those obtained for the HF breed, but inferior to those of the Simmental breed. Young Simmental bulls fed in the same way (with the same type of fodder) attained significantly higher daily weight gains in the control fattening, and the carcasses after slaughtering had better conformation.

\section{References}

A d a m c zyk K., F e leńczak A., Jamrozy J., S zarek J. (2008). Conservation of Polish Red cattle. Slov. J. Anim. Sci., 41: 72-76.

Alberti P., Panea B., Sañudo C., Olleta J.L., Ripoll G., Ertbjerg P., Christensen M., Gigli S., Failla S., Concetti S., Hocquette J.F., Jailler R., Rudel S., Ren and G., Nute G.R., R i chards o n R.I., Wi 11 i a m s J.L. (2008). Live weight, body size and carcass characteristics of young bulls of fifteen European breeds. Livest. Sci., 114: 19-30. 
B arłowska J. (2007). Nutritional value and technological usability of milk from cows of 7 breeds maintained in Poland (in Polish). Wyd. AR Lublin, 321, 112 pp.

Chabuz W., Teter W., S tan ek P., Litwińczuk Z. (2013). Evaluation of cattle husbandry effectiveness in farms maintaining the native breeds included into the programme of protection of genetic resources (in Polish). Rocz. Nauk. PTZ, 9, 1: 19-28.

Ch or o s z y Z., Ch or o s z y B. (2005). The possibility of using Polish Red Cattle for beef production (in Polish). Wiad. Zoot., 43, 2: 73-78.

Ci eśl a r P., W a w r z y ń c za k S. (1978). Fattening of young bulls of Polish Red and Red-and-White breed and their crossbreds using complete feed (in Polish). Rocz. Nauk. Zoot. Monogr. Rozpr., 12: $32-49$.

Dannenberger D., Nuernberg K., Nuernberg G., Ender K. (2006). Carcass- and meat quality of pasture vs concentrate fed German Simmental and German Holstein bulls. Arch. Tierz., 49: 315-328.

Hiemstra S.J., De Haas Y., Mäki-Tanila A., Gandini G. (2010). Local cattle breeds in Europe: Development of policies and strategies for self-sustaining breeds. Wageningen Academic Publishers, The Netherlands, $154 \mathrm{pp}$.

Holló G., Nuernberg G., Somogyi T., Anton I., Holló I. (2012). Comparison of fattening performance and slaughter value of local Hungarian cattle breeds to international breeds. Arch. Tierz., 55: 1-12.

Litwińczuk Z. (1979). The fattening of Lowland Black and White young bulls up to over $450 \mathrm{~kg}$ using a pasture in summer and grass silage in winter (in Polish). Rocz. Nauk. Zoot., 6: 277-287.

Litwi ń c z u k Z. (2011). Editor. Protection of genetic resources of livestock and wild animals (in Polish). PWRiL, Warszawa, Poland, 295 pp.

Litwińczuk Z., B arłowska J., Chabuz W., Brodziak A. (2012 a). Nutritional value and technological suitability of milk from cows of three Polish breeds included in the genetic resources conservation programme. Ann. Anim. Sci., 12: 423-432.

Litwińczuk Z., Chabuz W., Domaradzki P., Jankowski P. (2012 b). Slaughter value of young Polish Black-and-White, White-Backed, Polish Holstein-Friesian and Limousin bulls under semi-intensive fattening. Ann. Anim. Sci., 12: 159-168.

O przą d e k J., D y m n i cki E., R e k lew sk i Z. (2007). Changes in the growth rate and carcass tissue composition of young cattle depending on breed (in Polish). Rocz. Nauk. PTZ, 3: 103-109.

Reklewski Z., Jasiorowski H., Stolzman M., Łukaszewicz M., De Laurans A. (1985). Testing of different strains of Friesian cattle in Poland II. Beef performance of male crossbreds of different Friesian cattle strains under intensive feeding conditions. Livest. Prod. Sci., 12: $117-129$.

R o mer J., Głow a c iń sk a M., K o n o p k a S., O s i ę g łow sk i S. (1978). Crossbreeding results of cows of Lowland Black-and-White breed with bulls of French beef breeds and Simmental breed (in Polish). Biul. Inf. IZ, 3-4: 3-20.

$\mathrm{S} \mathrm{pal} \mathrm{ta} \mathrm{ba} \mathrm{k} \mathrm{E} \mathrm{E.} \mathrm{(2009).} \mathrm{Economic} \mathrm{aspects} \mathrm{of} \mathrm{alternative} \mathrm{ways} \mathrm{of} \mathrm{protective} \mathrm{cattle} \mathrm{rearing} \mathrm{illustrated}$ with Polish Red (in Polish). Rocz. Nauk Roln., ser. G 96, 3: 244-255.

S zarek J., A d a m c zyk K., Fe le n c zak A. (2004). Polish Red cattle breeding: past and present. Anim. Gen. Res. Inf., 35: 21-35.

Trautman J., Tarkow sk i J., Ka mien i c ki K., G n y p J. (1990). Characteristics of breeding Simmental cattle in Poland (in Polish). PWN, Warszawa, Poland, 71 pp.

$\mathrm{Z}$ a 1 e w s k i W. (1965). Investigations on fattening and slaughtering value of bullocks of the Polish Red, Lowland Black and White and the crosses of these breeds in their different final weights (in Polish). Rocz. Nauk Roln., ser. B, 85: 211-233.

Z i e miński R. (1993). Assessment of fattening and slaughter value of NCB bulls and their crossbreeds with Holstein-Friesian cattle (in Polish). Pr. Mat. Zoot., 44: 91-99.

Received: 18 IX 2013

Accepted: 13 XII 2013 